\title{
Statistical Evaluation of Indoor Air Quality Parameters in Classrooms of a University
}

\author{
Zeki Argunhan $^{1}$ and Ali Serkan Avci ${ }^{2}{ }^{2}$ \\ ${ }^{1}$ Mechanical Engineering, Faculty of Engineering and Architecture, Bitlis Eren University, Bitlis, Turkey \\ ${ }^{2}$ Energy Systems Engineering, Technology Faculty, Batman University, Batman, Turkey \\ Correspondence should be addressed to Ali Serkan Avci; aliserkan.avci@batman.edu.tr
}

Received 30 November 2017; Revised 31 January 2018; Accepted 5 February 2018; Published 18 March 2018

Academic Editor: Julio Diaz

Copyright ( 2018 Zeki Argunhan and Ali Serkan Avci. This is an open access article distributed under the Creative Commons Attribution License, which permits unrestricted use, distribution, and reproduction in any medium, provided the original work is properly cited.

\begin{abstract}
This study was carried out in order to determine the indoor air quality of the classrooms existing in university (Turkey). Relative humidity, temperature, carbon dioxide, radon, and particulate matters $\left(\mathrm{PM}_{0.5}, \mathrm{PM}_{1.0}, \mathrm{PM}_{2.5}, \mathrm{PM}_{5.0}\right.$, and $\left.\mathrm{PM}_{10}\right)$ were taken into account as the parameters of indoor air quality measurements. The results obtained from the present work were interpreted by comparing them with the standards of different countries. The relations between all parameters were statistically examined by means of correlation and regression analysis in SPSS 17 statistical program. As a result, it was observed that indoor temperature was lower than the standards, yet carbon dioxide and PM values were higher than the upper limit, but relative humidity level was within comfort conditions. The average indoor radon concentrations were found to be below the recommended reference levels for International Commission on Radiological Protection (ICRP), yet it was seen that the results were relatively higher in comparison with the worldwide values. In addition, it was determined that there was a meaningful relation between outdoor relative humidity, indoor relative humidity, and particulate matters in different diameters. Some solutions were suggested for the treatment of the indoor air quality for each parameter.
\end{abstract}

\section{Introduction}

Indoor air pollution is defined as the existence of pollutants (particulate matter, volatile organic compounds, inorganic compounds, biological, physical and chemical factors, etc.) in indoor air of nonindustrial buildings. These pollutants have a negative impact on human body. To protect and prevent the individuals from the negative health effects of pollutants, "Indoor Air Quality" has been developed as a research field.

According to reports of World Health Organization (WHO), people in urban areas spend about $90 \%$ of their time indoor, that is to say, $70 \%$ in workplaces and $20 \%$ in their houses $[1,2]$. According to the data of Environmental Protection Agency (EPA), the level of indoor pollutants is 2-5 times more than that of outdoor pollutants [3].

Recently, indoor air quality has become a parameter needed to be emphasized at educational institutions. Almost all students are exposed to indoor air in school buildings during their educational life. In these institutions, pollutants from several sources affect health, comfort, and performance of students and employees in a negative way, especially, due to the harmful impact on memory and concentration of students, students facing learning problems [4]. Classrooms and school environments are highly polluted because of the following reasons: crowded classrooms, short break times, low ventilation during breaks, inadequacy in providing fresh air, absence of mechanical ventilator, unplanned construction of ventilation system, factors bringing pollutants from outdoor, the existence of impermeable windows, and high radon levels. The reasons of existence of radon in indoor spaces are underground waters and building materials containing radon. Radon enters indoor through gaps around drainpipes, sewer pumps, and cracks in the connections of wall tiles. The amount and density of radon indoor are related to several factors such as concentration of radon in surrounding rock and soil, the amount of radon in soil around, porosity and permeability of soil, existence of ventilator or heating, ventilating, pressure difference between soil and 
building, or stack effect between different places of the building.

When studies on indoor air quality in educational institutions are examined, it is seen that the concentrations of pollutants are determined, and the relations between them are discussed. For instance, the relation between $\mathrm{CO}_{2}$ concentration and student absences was investigated [5]. Lin and Peng (2010) evaluated the state of knowledge all over the world regarding $\mathrm{PM}_{10}, \mathrm{PM}_{2.5}$, and ultrafine particles in classrooms of elementary schools [6]. Branis et al. (2005) studied correlation coefficient between $\mathrm{PM}_{10}, \mathrm{PM}_{2.5}$, and $\mathrm{PM}_{1}$ concentrations in three different points in a classroom for 12 hours [7]. Bayer et al. (1999) searched the factors having negative impacts on indoor air quality in schools [8]. Mcleod (2008) statistically evaluated the values of $\mathrm{CO}_{2}$, temperature, relative humidity, and total concentration of fungal spore in a school [9]. Smedje et al. (2006) carried out measurements of $\mathrm{PM}_{10}, \mathrm{PM}_{1}, \mathrm{NO}_{2}$, and $\mathrm{O}_{3}$ values in indoor and outdoor environments of schools in Switzerland [10].

Besides, the levels of indoor air pollutants were determined and their effects on health were analyzed in other interior environments. Hazar et al. (2014) evaluated the perceived risk of exposure of indoor residential radon among health care providers in urban and rural health centers [11]. Vimalanathd and Babu (2014) studied the influence of indoor environment on the performance, productivity health, and well-being of office workers [12]. Zong et al. (2012) measured particulate matter with a diameter less than $2.5 \mu \mathrm{m}$, elemental carbon and organic carbon in the kitchen, bedroom, and outdoors of a rural environment and nonsmoking household [13]. Hwang and Kim (2013) evaluated the indoor air quality in Open-Plan Offices [14], and Tan et al. investigated indoor air pollutant emissions due to energy use in residential buildings [15]. Dasgupta et al. (2006) employed regression analysis on data after observing $\mathrm{PM}_{10}$ value in Bangladesh [16]. Bucur et al. (2015) assessed the air quality inside a wooden church in Bucharest [17]. In China, Xiang et al. (2016) investigated the indoor air quality in kitchens where traditional stoves without chimney, improved stoves without chimney, and LPG stoves are used [18].

In addition to such studies essentially focusing on indoor air quality in various environments, the present investigation aims to exhibit how much outdoor air pollutants affect indoor air quality in Batman (Turkey) city which has second of worst outdoor air quality values according to $\mathrm{PM}_{2.5}$ annual mean in Europe [19]. For that purpose, the indoor air quality in the classrooms of Central and West Raman Campuses in Batman University was determined and some suggestions to improve the quality were proposed. Indoor and outdoor measurements were performed simultaneously; and temperature $(T)$, relative humidity $(\mathrm{RH})$, carbon dioxide $\left(\mathrm{CO}_{2}\right)$, radon $(\mathrm{Ra})$, and particulate matters in different diameters (PM) were considered as indoor air quality parameters. The same parameters were used for outdoor air. Data obtained for these parameters were used in regression analysis. Due to the absence and scarcity of such investigations regarding the aforementioned issues in Batman city and the study region (southeastern Anatolia), respectively, it is believed that the present work would set forth a significant source of knowledge for future studies to be carried out in the region.

\section{Materials and Methods}

2.1. Materials. To determine indoor air quality, measurements were taken in the classrooms of Faculty of Art and Science and Faculty of Engineering and Architecture in West Raman Campus and the rectorate building in Central Campus of Batman University. The measurements were carried out between September and May which is the education period. While measurements for Central Campus were performed between September and May, they were performed for West Raman Campus between February and May since the construction of West Raman Campus was completed in January.

2.2. Measuring Instruments. Among the equipment used; we had "Extech CO250 Portable Indoor Air Quality $\mathrm{CO}_{2}$ Meter" used for measurements of $\mathrm{CO}_{2}$. This device was used to measure the level of carbon dioxide between 0 and $5000 \mathrm{ppm}$, and nondispersive infrared was employed as the measurement principle. With the use of AlphaGUARD PQ 2000PRO instrument, short-term radon activity concentration values as well as air temperature humidity, pressure parameters were measured. With this portable instrument, radon activity concentrations could be measured with the range $2-2000000 \mathrm{~Bq} / \mathrm{m}^{3}$. Data analyses, processing, and storage were achieved with DataEXPERT software specially written for AlphaGUARD [20]. Measurement points were selected on the ground floor and basement since the most important contributions to indoor radon come from outside air and diffusion from the ground. Detector was kept on in a classroom at a distance of about $30 \mathrm{~cm}$ from the wall and $1.5-2 \mathrm{~m}$ high from the floor for about $24 \mathrm{~h}$ in diffusion mode. The present time was set at $10 \mathrm{~min}$ measurement interval and the average value was recorded. The 88 data points were taken from each classroom which might present an idea of the diurnal radon variation inside. Moreover, particle concentration, temperature, and humidity were quantified with Lighthouse Handheld 3016 IAQ. This device has 4 million particulate $/ \mathrm{ft}^{3}$ concentration and 1 CFM (2.83 LPM) flow rate. It can measure particles within a range of $0.3-10 \mu \mathrm{m}$ in size, in the range of $0-50^{\circ} \mathrm{C}$ temperature and with a range of $5-90 \%$ relative humidity.

Depending on particle diameters, $\mathrm{PM}_{0.3}, \mathrm{PM}_{0.5}, \mathrm{PM}_{1.0}$, $\mathrm{PM}_{2.5}, \mathrm{PM}_{5.0}$, and $\mathrm{PM}_{10}$ can be measured simultaneously in 6 channels, with temperatures between 0 and $50^{\circ} \mathrm{C}$ and humidity level between 15 and $90 \mathrm{RH} \%$. These parameters were also quantified simultaneously for outdoor air.

Measurements were done twice a week, and the equipment was used 1 meter above the ground to get a reliable measurement. In addition, 4 different measurement points were selected in the classrooms after the course started and measurements were conducted during the course. Measurement times were set between 08:00 and 09:00, between 13:00 and 14:00 and between 16:00 and 17:00. Then, the data obtained from the measuring points were analyzed to where the pollutants were exposed (glass, door 
TABLE 1: Comparison of indoor air quality standards of different countries.

\begin{tabular}{|c|c|c|c|c|}
\hline Countries & $\mathrm{CO}_{2}$ & Particle matter & $\begin{array}{l}\text { Relative } \\
\text { humidity }\end{array}$ & Temperature \\
\hline USA ASHRAE $^{\mathrm{a}}$ & 1000 ppm & $\begin{array}{c}\mathrm{PM}_{10}<75 \mu \mathrm{g} / \mathrm{m}^{3} \text { (annual } \\
\text { average) }\end{array}$ & $\% 30-60$ & $20-25.5^{\circ} \mathrm{C}$ \\
\hline USA/EPA/NAAQS ${ }^{\mathrm{b}}$ & - & $50 \mathrm{gr} / \mathrm{m}^{3}$ (1 year $)$ & - & - \\
\hline USA NIOSH ${ }^{c}$ & $\begin{array}{c}5000 \mathrm{ppm} \\
30000 \mathrm{ppm}(15 \mathrm{~min})\end{array}$ & - & - & - \\
\hline USA OSHA $^{\mathrm{d}}$ & $\begin{array}{c}10000 \text { ppm } \\
30000 \text { ppm (15 dak.) }\end{array}$ & $\begin{array}{c}5 \mathrm{mg} / \mathrm{m}^{3} \text { (8 hours) } \\
\text { Respirable dust }\end{array}$ & - & - \\
\hline USA ACGIH $^{\mathrm{e}}$ & $\begin{array}{c}5000 \mathrm{ppm} \\
9000 \mathrm{ppm}(15 \mathrm{~min})\end{array}$ & $3 \mathrm{mg} / \mathrm{m}^{3}$ (8 hours) & - & - \\
\hline Germany $\mathrm{MAK}^{\mathrm{f}}$ & $\begin{array}{c}5000 \mathrm{ppm} \\
9000 \mathrm{ppm}(15 \mathrm{~min})\end{array}$ & - & $\% 30-70$ & $20-26^{\circ} \mathrm{C}$ \\
\hline Canada & $3500 \mathrm{ppm}$ & $\begin{array}{c}\left.\mathrm{PM}_{2.5}<40 \mu \mathrm{g} / \mathrm{m}^{3} \text { (8 hours }\right) \\
100 \mu \mathrm{g} / \mathrm{m}^{3} \text { (1 hour) }\end{array}$ & $\begin{array}{l}\% 30-80 \\
\text { (summer) } \\
\% 30-55 \\
\text { (winter) }\end{array}$ & - \\
\hline China & - & $\mathrm{PM}_{10}<150 \mu \mathrm{g} / \mathrm{m}^{3}$ & - & - \\
\hline WHO & - & $\begin{array}{c}\mathrm{PM}_{10}<20 \mu \mathrm{g} / \mathrm{m}^{3} \text { (annual } \\
\text { average) } \\
\mathrm{PM}_{10}<50 \mu \mathrm{g} / \mathrm{m}^{3}(24 \\
\text { hours })\end{array}$ & - & - \\
\hline England & - & $\mathrm{PM}_{10}<50 \mu \mathrm{g} / \mathrm{m}^{3}$ & - & - \\
\hline Norway & - & $\mathrm{PM}_{2.5}<20 \mu \mathrm{g} / \mathrm{m}^{3}$ & - & - \\
\hline European Union & - & $\mathrm{PM}_{2.5}<35 \mu \mathrm{g} / \mathrm{m}^{3}$ & - & - \\
\hline Hong Kong & $\begin{array}{c}800 \text { ppm (Level 1) } \\
1000 \text { ppm (Level 2) }\end{array}$ & $\begin{array}{c}\mathrm{PM}_{10}<20 \mu \mathrm{g} / \mathrm{m}^{3}(\text { Level } 1) \\
\mathrm{PM}_{10}<180 \mu \mathrm{g} / \mathrm{m}^{3} \text { (Level 2) } \\
(8 \text { hours average) }\end{array}$ & $\% 40-70$ & $20-25.5^{\circ} \mathrm{C}$ \\
\hline
\end{tabular}

${ }^{a}$ ASHRAE: American Society of Heating, Refrigerating and Air-Conditioning Engineers, ${ }^{b}$ EPA/NAAQS: Environmental Protection Agency/National Ambient Air Quality Standards, ${ }^{c}$ NIOSH: National Institute of Occupational Safety And Health, ${ }^{\mathrm{d} O S H A}$ : Occupational Safety and Health Administration, ${ }^{\mathrm{e}}$ ACGIH: American Conference of Governmental Industrial Hygienists, and ${ }^{\mathrm{f}} \mathrm{MAK}$ : German Maximale Arbeitsplatz Konzentrationen.

edges, wooden furniture, etc.) and their average values were calculated.

\subsection{The Features of Central and West Raman Campus.} Central Campus, one of the test locations, is located on a highway and in the residential area. Because of this, it is exposed to air pollution due to exhaust gases from traffic and heating systems in winters. Structural features of ClassroomI and Classroom-II, where measurements are performed, are similar. Heating is conducted via a central heating system; however, there is no cooling system. In both classrooms, there are two double glazed windows in size $180 \times 150 \mathrm{~cm}$. Desks and tables are MDF veneered compressed chipboards, floor is precast slabs, doors are woodwork, and windows are fanlight model with an aluminum frame. Classrooms are $60 \mathrm{~m}^{2}$ and for 40 people.

West Raman Campus was put into action in January, and for the time being, there are only university buildings in the campus. There is a sparse traffic around the campus since it is located $14 \mathrm{~km}$ away from town center. In ClassroomsIII and Classroom-IV, where measurements are performed, ventilation is done by means of natural methods. For heating, panel radiators are used in central heating system. In the classrooms, there are MDF veneered compressed chipboards desks and tables, Teflon boards, and two double glazed windows. These windows are fanlight model with an aluminum frame. Classrooms are $70 \mathrm{~m}^{2}$ and for 50 people.

The standards of the parameters, $\mathrm{CO}_{2}$, particulate matter, temperature, and relative humidity used in this study, are given in the Table 1 with respect to the countries.

2.4. Methods. SPSS 17 program was utilized for statistical evaluation of measurement data. Via this program, median, average, standard deviation and maximum and minimum values were calculated. In addition, the relations and correlation coefficients between parameters for indoor and outdoor air were evaluated. Correlation coefficient showed a statistical relationship between independent variables and submitted a value between -1 and 1 . While the positive and negative values showed a positive linear relationship and relationships in opposite directions, respectively, 0 values showed that there was no relation between the variables. The statistically significant level of this relationship was determined by comparing the calculated $p$ value and a chosen significance level (usually $\alpha$ is chosen as 0.05 ). If $p$ value is smaller than the significance level, the relationship is statistically significant. 
TABLE 2: The statistical values of all the measurements.

\begin{tabular}{|c|c|c|c|c|c|c|c|}
\hline & Parameters & $\begin{array}{c}\text { Number Of } \\
\text { measurements } \\
(N)\end{array}$ & Average & Median & $\begin{array}{l}\text { Standard } \\
\text { deviation }\end{array}$ & Minimum & Maximum \\
\hline \multirow{10}{*}{ Indoor } & Number of people & 136 & 18.85 & 19 & 6.802 & 3 & 34 \\
\hline & Temperature $\left({ }^{\circ} \mathrm{C}\right)$ & 136 & 19.68 & 19.4 & 3.321 & 12.1 & 28.6 \\
\hline & $\begin{array}{c}\text { Relative humidity } \\
\text { (\%) }\end{array}$ & 136 & 43.64 & 43.5 & 14.738 & 19.5 & 73.3 \\
\hline & $\begin{array}{l}\mathrm{CO}_{2} \\
(\mathrm{ppm})\end{array}$ & 136 & 1415.72 & 1337.5 & 642.817 & 504 & 2873 \\
\hline & $\begin{array}{l}\mathrm{PM}_{0.5} \\
\left(\mu \mathrm{g} / \mathrm{m}^{3}\right)\end{array}$ & 136 & 15.96 & 15.5 & 8.32 & 2 & 34 \\
\hline & $\begin{array}{c}\mathrm{PM}_{1} \\
\left(\mu \mathrm{g} / \mathrm{m}^{3}\right)\end{array}$ & 136 & 30.8 & 29.5 & 12.541 & 5 & 71 \\
\hline & $\begin{array}{l}\mathrm{PM}_{2.5} \\
\left(\mu \mathrm{g} / \mathrm{m}^{3}\right)\end{array}$ & 136 & 48.37 & 47.5 & 19.753 & 8 & 113 \\
\hline & $\begin{array}{l}\mathrm{PM}_{5.0} \\
\left(\mu \mathrm{g} / \mathrm{m}^{3}\right)\end{array}$ & 136 & 69.64 & 66.5 & 29.36 & 11 & 147 \\
\hline & $\begin{array}{c}\mathrm{PM}_{10} \\
\left(\mu \mathrm{g} / \mathrm{m}^{3}\right)\end{array}$ & 136 & 107.09 & 92.5 & 58.383 & 13 & 278 \\
\hline & $\begin{array}{l}\text { Radon } \\
\left(\mathrm{Bq} \cdot \mathrm{m}^{-3}\right)\end{array}$ & 88 & 46.8 & 44.5 & 18.2 & 21 & 116 \\
\hline \multirow{4}{*}{ Outdoor } & Temperature $\left({ }^{\circ} \mathrm{C}\right)$ & 136 & 14.85 & 13.8 & 6.471 & -1.2 & 29.5 \\
\hline & $\begin{array}{c}\text { Relative humidity } \\
(\%)\end{array}$ & 136 & 51.97 & 49.35 & 24.486 & 20.5 & 96.2 \\
\hline & $\begin{array}{l}\mathrm{CO}_{2} \\
(\mathrm{ppm})\end{array}$ & 136 & 465.6 & 452.5 & 70.121 & 342 & 661 \\
\hline & $\begin{array}{l}\mathrm{PM}_{10} \\
\left(\mu \mathrm{g} / \mathrm{m}^{3}\right)\end{array}$ & 136 & 76.3 & 64.5 & 46.7 & 11 & 289 \\
\hline
\end{tabular}

\section{Results and Discussion}

In Table 2, the statistical values of all the measured data are given. The descriptive statistics parameters are given as number of measurements, mean, median, and standard deviation, and minimum and maximum values.

3.1. Central and West Raman Campus Measurement Results. Average indoor temperature was ascertained as $19.68^{\circ} \mathrm{C}$ and the range of it was $12.10^{\circ} \mathrm{C}-28.60^{\circ} \mathrm{C}$ (Figure 1). These values are below the standards specified by ASHRAE, MAK, and Hong Kong. Average relative humidity was ascertained as $43.64 \%$ and the range of it was $19.50 \%-73.30 \%$ (Figure 2). It was observed that the average relative humidity complies with the ASHRAE standards which have a range of $30-60 \%$. Besides that, it satisfies comfort conditions of MAK, Canada, and Hong Kong. Average carbon dioxide $\left(\mathrm{CO}_{2}\right)$ value was ascertained as $1415.72 \mathrm{ppm}$ and the range of it was $504-2873 \mathrm{ppm}$ (Figure 3). It was observed that average carbon oxide value is $1000 \mathrm{ppm}$ above the ASHRAE standards. As a result, all average values of indoor air quality in Central Campus were more adverse than that of West Raman Campus.

Average indoor $\mathrm{PM}_{2,5}$ values were found as $37 \mu \mathrm{g} / \mathrm{m}^{3}$ and the range of it was $8-113 \mu \mathrm{g} / \mathrm{m}^{3}$. These results exceeds the upper limits set by Norway and European Union which are $\mathrm{PM}_{2.5}<20 \mu \mathrm{g} / \mathrm{m}^{3}$ and $\mathrm{PM}_{2.5}<35 \mu \mathrm{g} / \mathrm{m}^{3}$, respectively.
Average indoor $\mathrm{PM}_{10}$ values were found as $107.09 \mu \mathrm{g} / \mathrm{m}^{3}$ and the range of it was $13-278 \mu \mathrm{g} / \mathrm{m}^{3}$. Average $\mathrm{PM}_{10}$ values are above the ASHRAE upper limit which is $75 \mu \mathrm{g} / \mathrm{m}^{3}$. Moreover, it is also higher than the upper limits of $\mathrm{PM}_{10}$ set by England, World Health Organization (WHO), Hong Kong 1st level values which are $50 \mu \mathrm{g} / \mathrm{m}^{3}, 20 \mu \mathrm{g} / \mathrm{m}^{3}$, and $20 \mu \mathrm{g} / \mathrm{m}^{3}$, respectively. However, this value is below the upper limits set by China and Hong Kong 2nd level values which are $150 \mu \mathrm{g} / \mathrm{m}^{3}$ and $180 \mu \mathrm{g} / \mathrm{m}^{3}$, respectively (Figure 4 ).

Indoor radon concentrations in the study varied from 21 to $116 \mathrm{~Bq} \cdot \mathrm{m}^{-3}$ and with $46 \mathrm{~Bq} \cdot \mathrm{m}^{-3}$ as arithmetical average. The skewness and kurtosis values for frequency distribution of radon concentration were found to have positive values. And the average indoor radon concentrations for the study were lower than action level of (200-600) Bq. $\mathrm{m}^{-3}$, advised by the ICRP [21], but were higher than the mean values reported for the buildings worldwide of $40 \mathrm{~Bq} \cdot \mathrm{m}^{-3}$ [22].

3.2. SPSS 17 Statistical Analysis Results. In Table 3, the significance levels and correlation coefficients $(r)$ among the parameters used in this study are given. The first value given in this table shows (Pearson) correlation coefficient and the second one (Sig; 2-tailed) shows two-tailed test and the last one $(N)$ shows the sample size. The significance level $(\alpha)$ is chosen as 0.05 . The values smaller than this level are significantly important. 


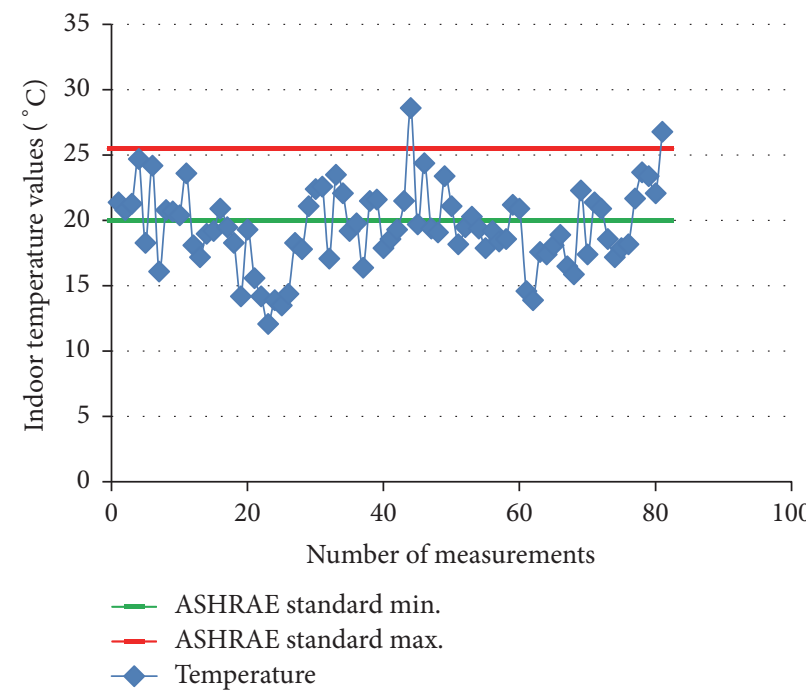

(a)

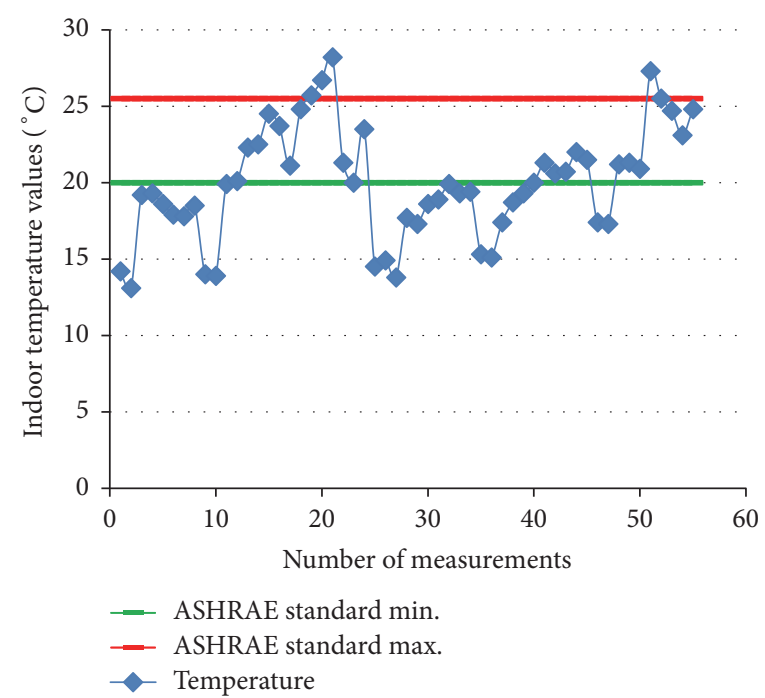

(b)

FIgURE 1: Indoor temperature change in Central Campus (a); indoor temperature change in West Raman Campus (b).

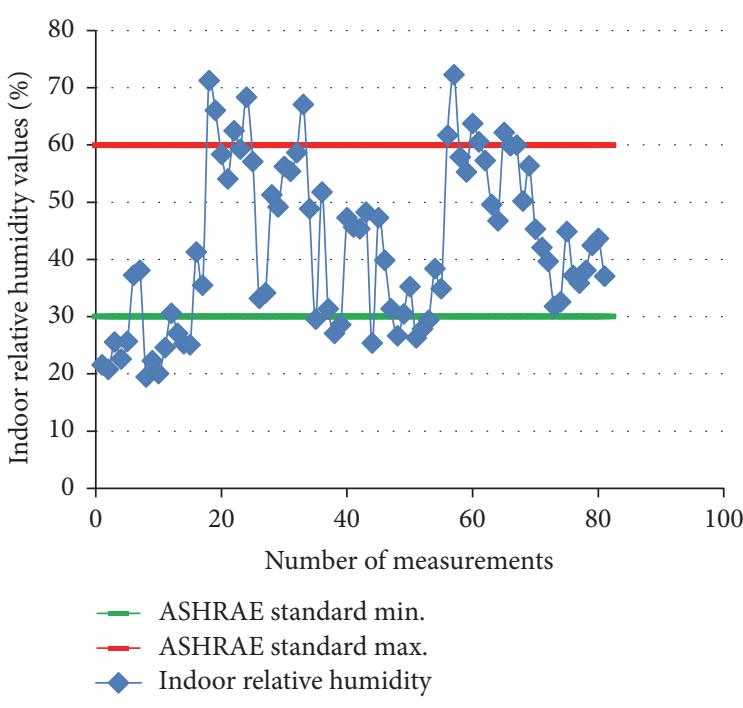

(a)

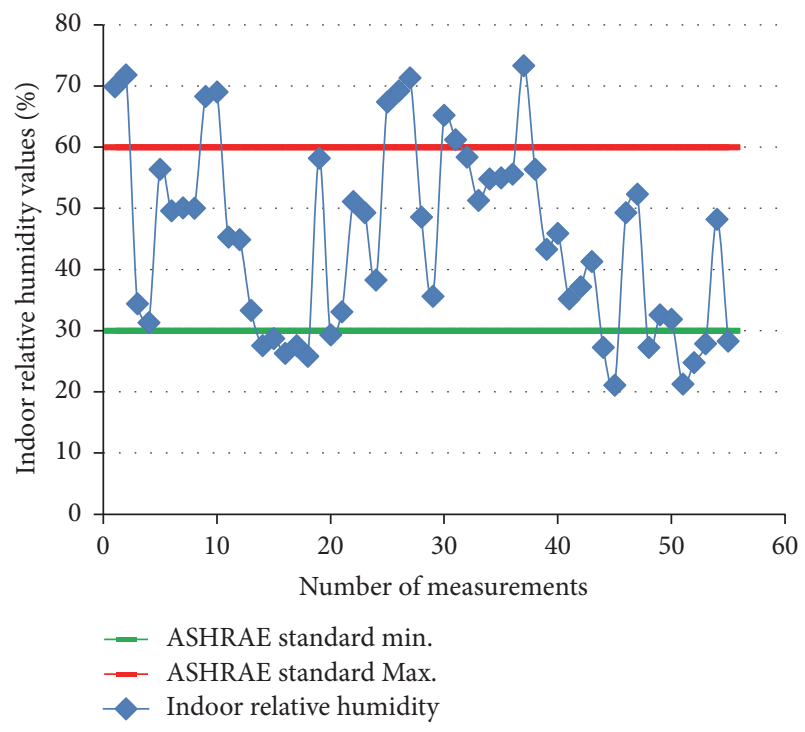

(b)

Figure 2: Indoor relative humidity change in Central Campus (a); indoor relative humidity change in West Raman Campus (b).

As it is seen in Table 3, the correlation coefficient between indoor $\mathrm{CO}_{2}$ amount and number of people is 0.768 . It is observed that, especially in winter season, since door and windows are closed, there is a significant increase in $\mathrm{CO}_{2}$ concentration depending on the number of people. The correlation coefficient between indoor $\mathrm{PM}_{10}$ values and number of people is 0.263 . This can be interpreted in a way that movements and activities of people increase the percentage of particle matter, and the classrooms are not ventilated sufficiently.

The correlation coefficient between indoor $\mathrm{CO}_{2}$ amount and indoor temperature is -0.409 . Because of the fact that there is natural air ventilation due to the open doors and windows and due to the increase in temperature in spring season, $\mathrm{CO}_{2}$ concentration decreases and this creates graphical fluctuations. The correlation coefficient between indoor temperature and indoor relative humidity is -0.540 . Due to the fact that the maximum humidity amount in air increases with an increase in temperature, relative humidity value decreases when temperature increases. The relations between parameters are given in Figure 5 .

As it is seen in Table 3, the correlation coefficient between indoor temperature and indoor $\mathrm{PM}_{10}$ values is -0.324 . It is observed that there is a relation at a small rate in negative direction. The reason for this is that the ventilation is natural in the spring. The correlation coefficient between indoor relative humidity and outdoor relative humidity is 0.940 . This leaks from outdoor to indoor and 


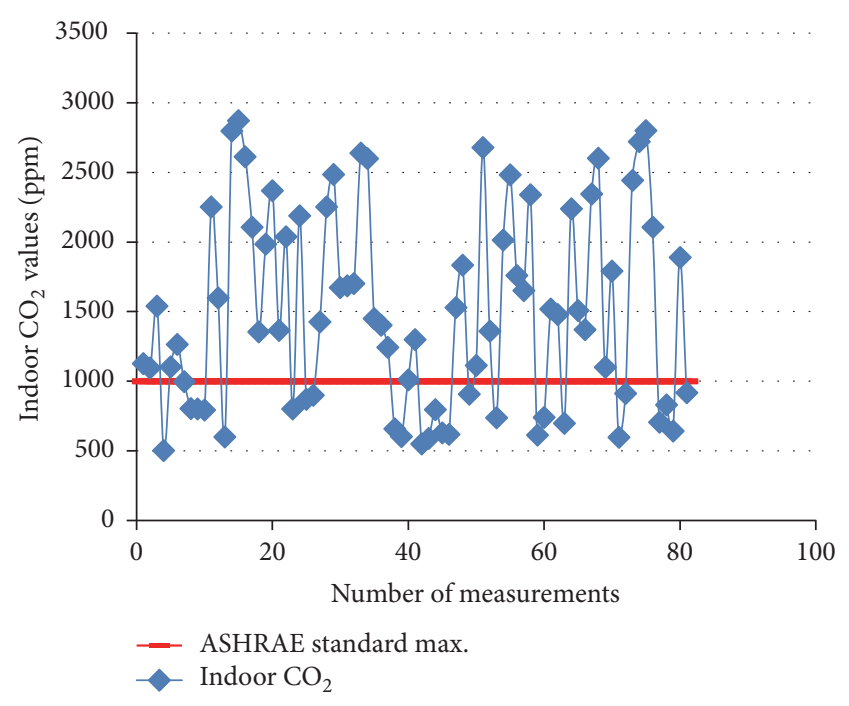

(a)

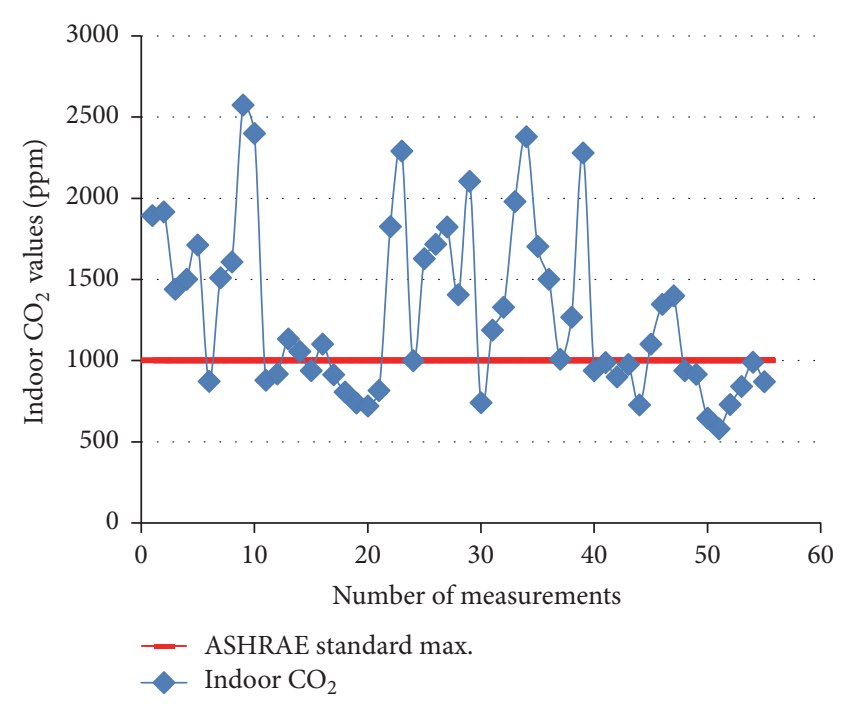

(b)

Figure 3: Indoor $\mathrm{CO}_{2}$ change in Central Campus (a); indoor $\mathrm{CO}_{2}$ change in West Raman Campus (b).

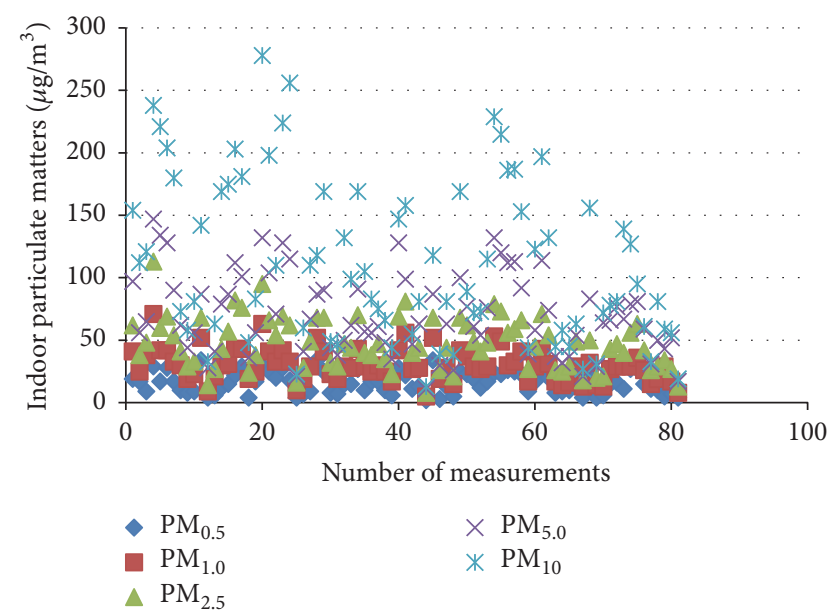

(a)

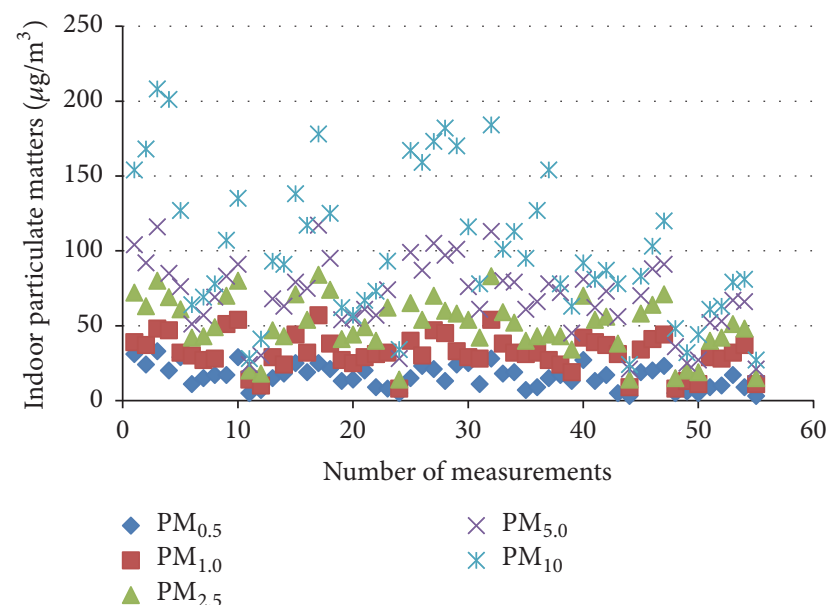

(b)

FIGURE 4: Indoor particulate matters $\left(\mathrm{PM}_{0.5}, \mathrm{PM}_{1.0}, \mathrm{PM}_{2.5}, \mathrm{PM}_{5.0}\right.$, and $\mathrm{PM}_{10}$ ) change in Central Campus (a); indoor particulate matters ( $\mathrm{PM}_{0.5}$, $\mathrm{PM}_{1.0}, \mathrm{PM}_{2.5}, \mathrm{PM}_{5.0}$, and $\mathrm{PM}_{10}$ ) change in West Raman Campus (b).

insufficient indoor heating system causes a high connection between these parameters. The correlation coefficient between outdoor $\mathrm{PM}_{10}$ and indoor $\mathrm{PM}_{10}$ values is 0.580 . This results from the fact that particulate matters easily leak from outdoor towards indoor. The correlation coefficient between indoor $\mathrm{PM}_{5.0}$ values and outdoor temperature is -0.261 . When the outdoor temperature increases, fresh air circulation occurs through open doors and windows. This causes a decrease in the amount of indoor particulate matters. The relations between these parameters are given in Figure 6.

The correlation coefficient between indoor $\mathrm{PM}_{1.0}$ and outdoor $\mathrm{PM}_{10}$ values is 0.447 . It is observed that there is a relation at a small rate in positive direction. The correlation coefficient between the outdoor temperature and indoor $\mathrm{PM}_{10}$ is 0.332 . There is a positive relation between parameters at a small rate. The correlation coefficient between indoor $\mathrm{PM}_{0.5}$ and indoor $\mathrm{PM}_{5.0}$ is 0.825 . This shows that particulate matters affect each other at a high level. The correlation coefficient between indoor $\mathrm{CO}_{2}$ amount and outdoor relative humidity is 0.287 . It is observed that there is a relation at a small rate in positive direction. The relations between these parameters are given in Figure 7.

\section{Conclusions}

It is observed that the indoor temperature values are below the standards. This shows that the heating system is insufficient in winter season, and the buildings are not insulated sufficiently and there is air escaping due to infiltration. To reach the comfort standards, an efficient central heating system can be recommended. 


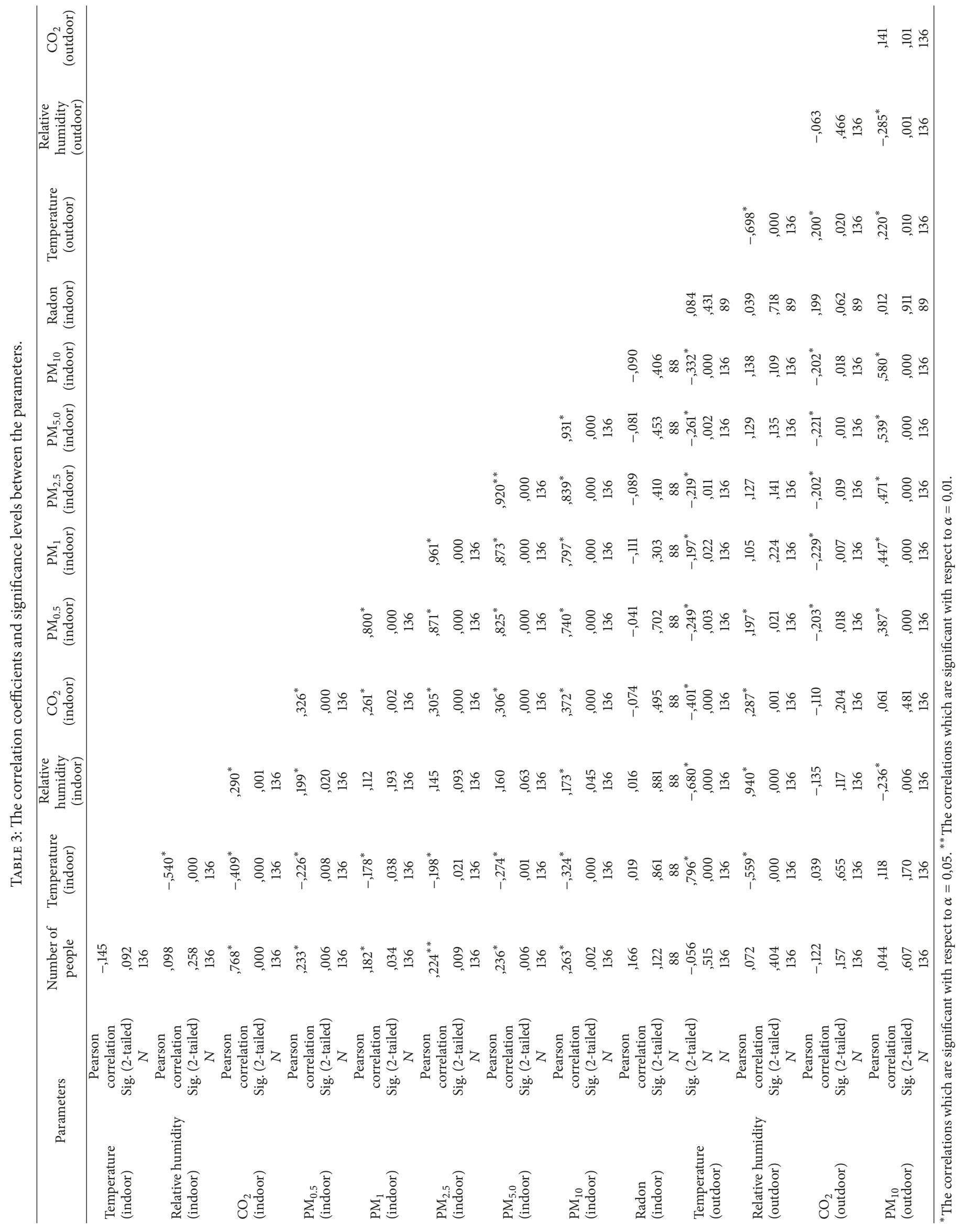




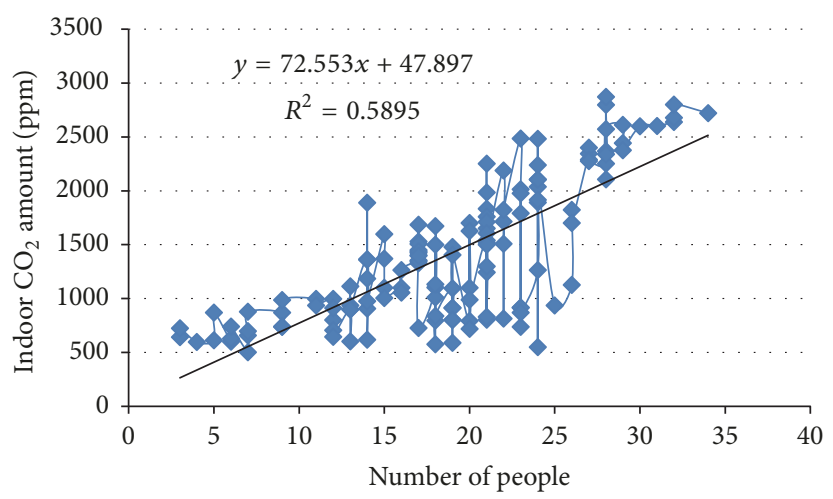

(a)

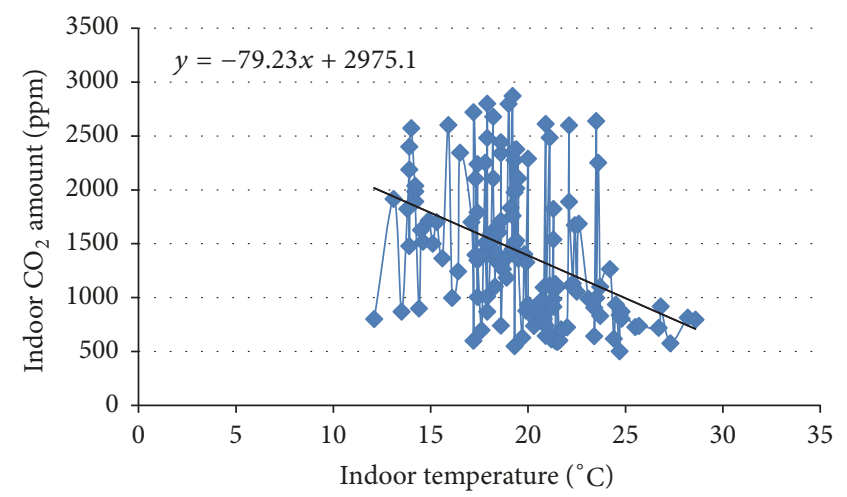

(c)

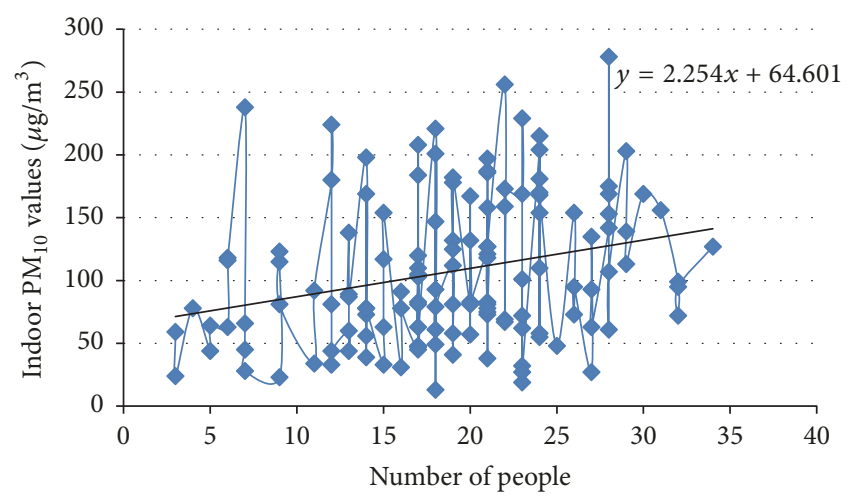

(b)

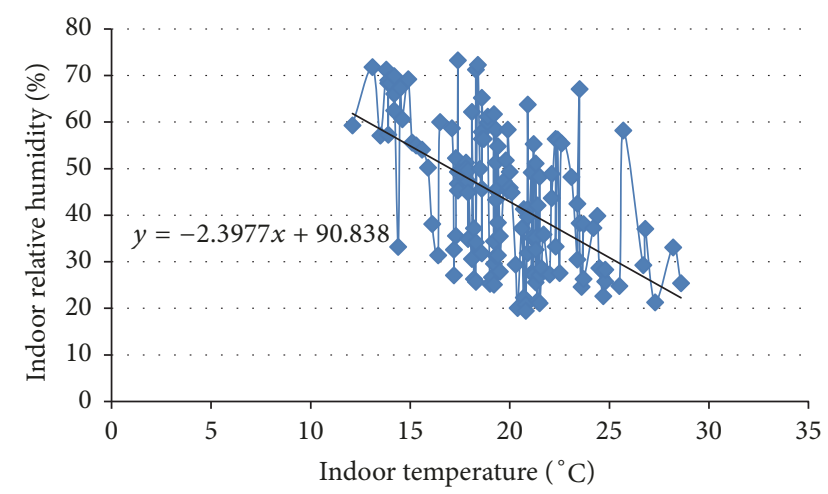

(d)

FIGURE 5: The relations among the parameters: (a) between indoor $\mathrm{CO}_{2}$ amount and number of people, (b) between indoor $\mathrm{PM}_{10}$ values and number of people, (c) between indoor $\mathrm{CO}_{2}$ amount and indoor temperature, and (d) between indoor temperature and indoor relative humidity.

The average relative humidity value satisfies comfort conditions. The fact that the high outdoor humidity level has an effect on indoor relative humidity shows that central heating system is insufficient. An effective air conditioning system is suggested to attain relative humidity standards.

Average indoor carbon dioxide $\left(\mathrm{CO}_{2}\right)$ value is higher than the ASHRAE standards. This is caused due to closed doors and windows in winters. The decrease in $\mathrm{CO}_{2}$ level in spring shows that there is air ventilation in classrooms, even it is not sufficient. An air ventilation system must be constructed to prevent the exceeding indoor $\mathrm{CO}_{2}$ levels convenient to standards.

The ratio of indoor/outdoor $\mathrm{PM}_{10}$ average values is calculated as 1.40. This shows that indoor particulate matter amount is higher than the outdoor values. Besides, the average indoor $\mathrm{PM}_{10}$ values in Central Campus are higher than the average found in West Raman Campus. This difference results from heavy traffic and emission pollutants. To control the amount of indoor particulate matter, air cleaning equipment must be used.

After determining the relations between indoor air quality parameters by using SPSS 17, correlation coefficient and significance levels are found. According to the significance level $(\alpha=0.05)$, it is found that there are strong positive relationships between the number of people and indoor $\mathrm{CO}_{2}$ level, also between the outdoor relative humidity and indoor relative humidity, and finally among the particulate matters $\left(\mathrm{PM}_{0.5}, \mathrm{PM}_{1.0}, \mathrm{PM}_{2.5}, \mathrm{PM}_{5.0}\right.$, and $\left.\mathrm{PM}_{10}\right)$. It is also found that there is a medium level positive relation between outdoor $\mathrm{PM}_{10}$ and indoor $\mathrm{PM}_{5.0}$ values. There is also a medium level of negative relation between indoor/outdoor temperature and relative humidity level. In addition, there are weak positive relations between outdoor $\mathrm{PM}_{10}$ values and indoor values of $\mathrm{PM}_{0.5}, \mathrm{PM}_{1.0}$, and $\mathrm{PM}_{2.5}$ and also between outdoor relative humidity and indoor $\mathrm{CO}_{2}$ levels. There are weak negative relations between indoor temperature and indoor $\mathrm{CO}_{2}$ and $\mathrm{PM}_{10}$ values and also between outdoor temperature and indoor $\mathrm{CO}_{2}, \mathrm{PM}_{5.0}$, and $\mathrm{PM}_{10}$ values. There is a very weak negative relation between the number of people and indoor $\mathrm{PM}_{0.5}, \mathrm{PM}_{1.0}, \mathrm{PM}_{2.5}$, and $\mathrm{PM}_{5.0}$ values. At a significance level of $\alpha(0.05)$, a relation between radon value and other parameters could not be found. It is thought that the reason for that situation is that radon level is always below a certain value.

The concentrations of indoor radon are found to be changing from place to place. This variation may be attributed to ventilation, humidity, temperature, climatic conditions, air circulation, and soil permeability and also occasionally to wind blowing among the buildings. 


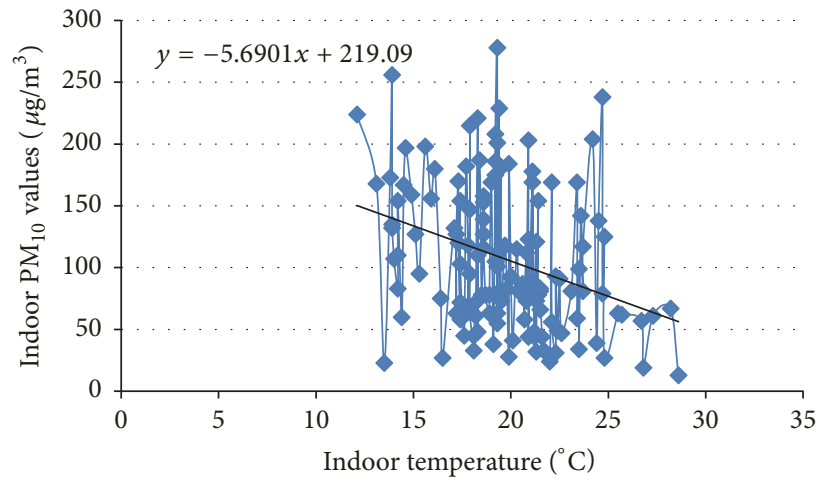

(a)

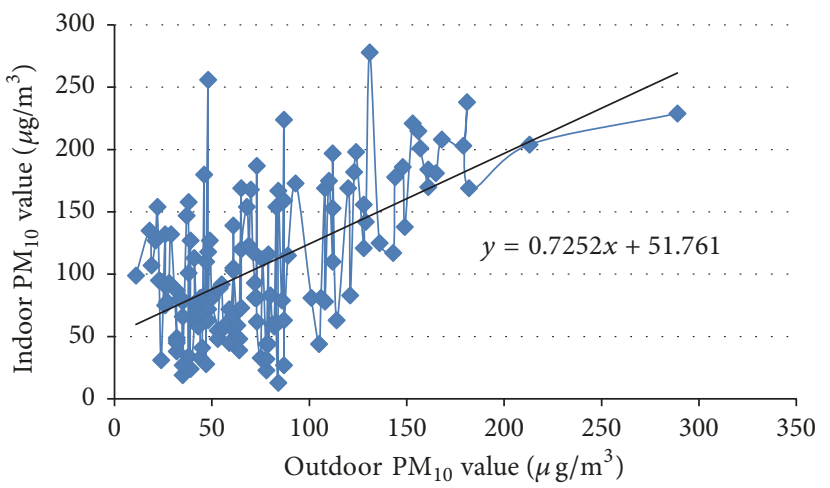

(c)

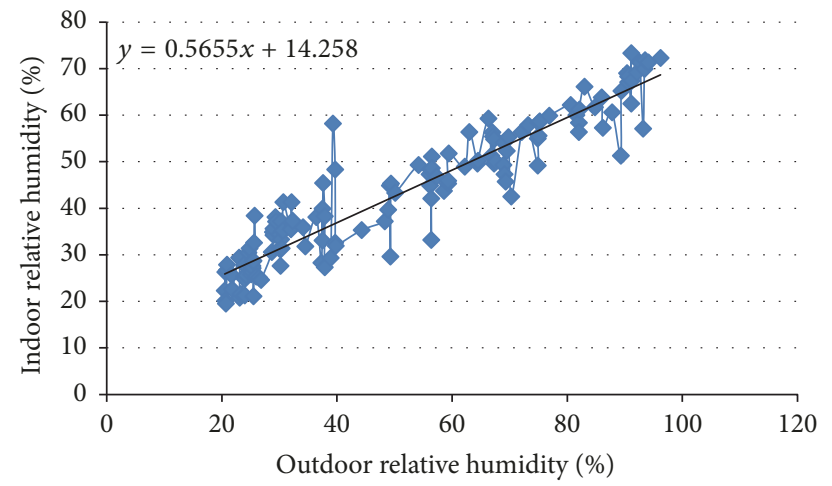

(b)

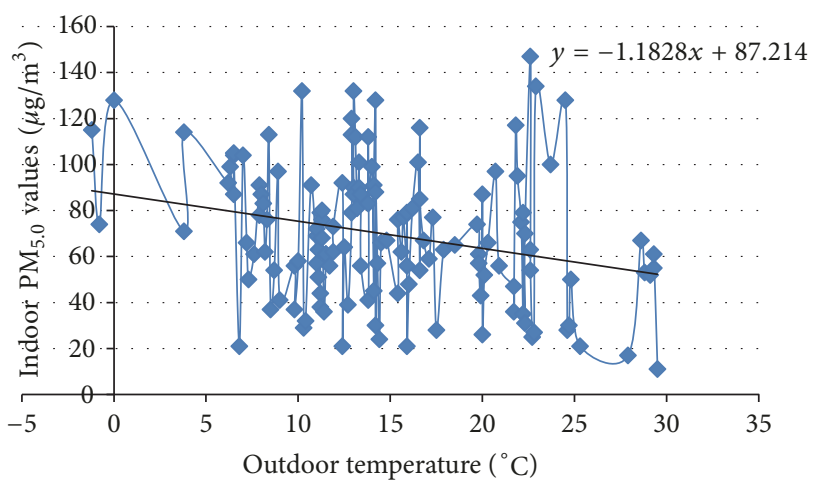

(d)

FIGURE 6: The relations among the parameters: (a) between indoor temperature and indoor $\mathrm{PM}_{10}$ values, (b) between indoor relative humidity and outdoor relative humidity, (c) between outdoor $\mathrm{PM}_{10}$ and indoor $\mathrm{PM}_{10}$ values, and (d) between indoor $\mathrm{PM}_{5.0}$ values and outdoor temperature.

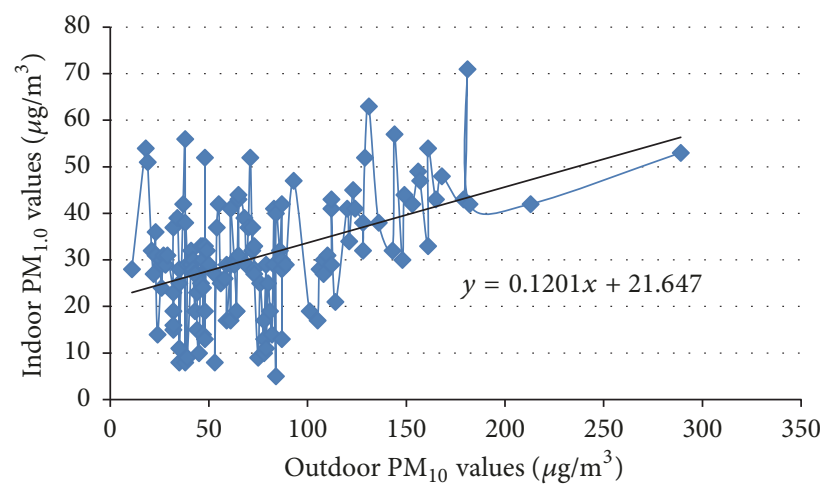

(a)

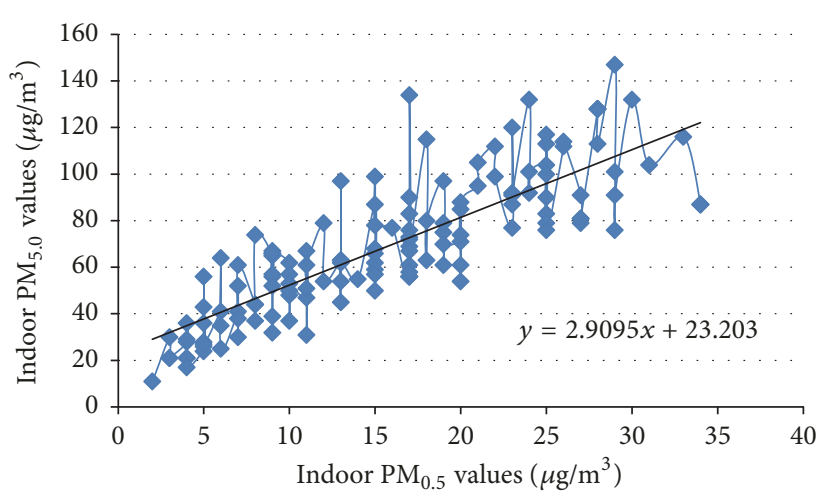

(c)

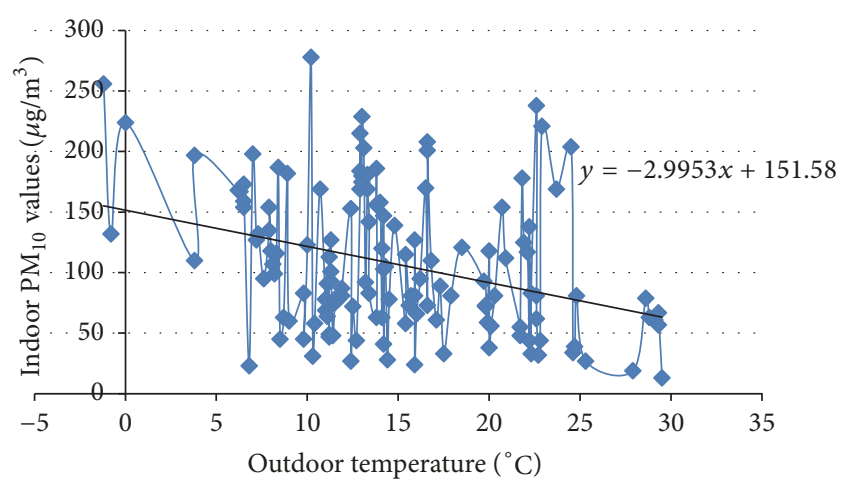

(b)

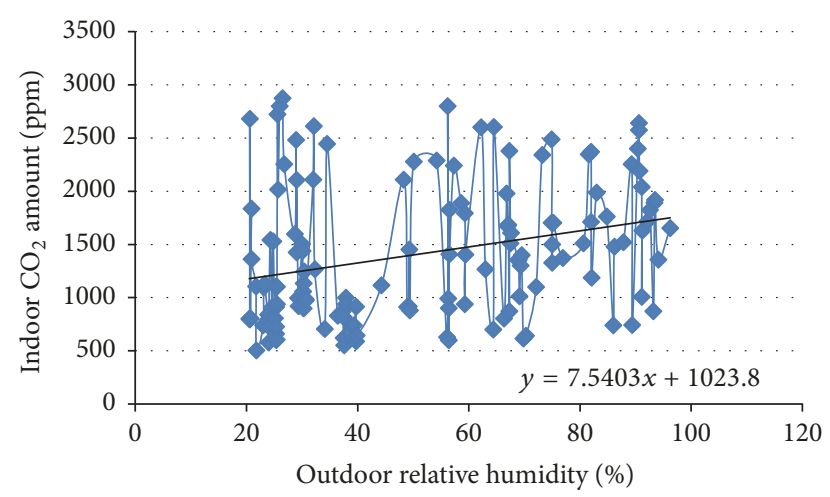

(d)

FIGURE 7: The relations among the parameters: (a) between indoor $\mathrm{PM}_{1.0}$ and outdoor $\mathrm{PM}_{10}$ values, (b) between the outdoor temperature and indoor $\mathrm{PM}_{10}$ values, (c) between indoor $\mathrm{PM}_{0.5}$ and indoor $\mathrm{PM}_{5.0}$ values, and (d) between indoor $\mathrm{CO}_{2}$ amount and outdoor relative humidity. 
It is important to build educational institutions outside the city center. This can decrease the level of exposure to exhaust gases led by traffic, air pollution caused by heating systems of settlements. It must also be ensured that the buildings should be built in the places where they can get enough sunlight.

\begin{tabular}{|c|c|}
\hline \multicolumn{2}{|c|}{ Abbreviations } \\
\hline ICRP: & $\begin{array}{l}\text { International Commission on } \\
\text { Radiological Protection }\end{array}$ \\
\hline WHO: & World Health Organization \\
\hline EPA: & Environmental Protection Agency \\
\hline ASHRAE: & $\begin{array}{l}\text { American Society of Heating Refrigerating } \\
\text { and Air-Conditioning Engineers }\end{array}$ \\
\hline NAAQS: & National ambient air quality standards \\
\hline NIOSH: & $\begin{array}{l}\text { National Institute of Occupational Safety } \\
\text { And Health }\end{array}$ \\
\hline OSHA: & $\begin{array}{l}\text { Occupational Safety and Health } \\
\text { Administration }\end{array}$ \\
\hline ACGIH: & $\begin{array}{l}\text { American Conference of governmental } \\
\text { Industrial Hygienists }\end{array}$ \\
\hline MAK: & $\begin{array}{l}\text { German Maximale Arbeitsplatz } \\
\text { Konzentrationen }\end{array}$ \\
\hline MDF: & Medium Density Fiberboard \\
\hline PM: & Particulate matter. \\
\hline
\end{tabular}

\section{Conflicts of Interest}

The authors declare that there are no conflicts of interest regarding the publication of this paper.

\section{References}

[1] Turkey Statistical Institute (Turkstat). Statistics by Theme, Population and Demography, 2017; Turkey, http://www.turkstat.gov .tr/PreTablo.do?alt_id=1047.

[2] World Health Organisation (WHO), Air Quality Guidelines for Europe, Second Edition, Regional Publications, European Series No. 91, Copenhagen, 2000.

[3] Environmental Protection Agency (EPA). Environmental Hazards in the Home. United States. 2016, http://library.hsh.com/ articles/homeowners-repeat-buyers/environmental-hazards-inthe-home/.

[4] Jr. R. S. Zimmerman, Indoor Air Quality Guidelines for Pennsylvania Schools, Pennsylvania Department of Health, Harrisburg, Pa, USA, 1999.

[5] D. G. Shendell, R. Prill, W. J. Fisk, M. G. Apte, D. Blake, and D. Faulkner, "Associations between classroom $\mathrm{CO} 2$ concentrations and student attendance in Washington and Idaho," Indoor Air, vol. 14, no. 5, pp. 333-341, 2004.

[6] C.-C. Lin and C.-K. Peng, "Characterization of indoor PM10, PM2.5, and ultrafine particles in elementary school classrooms: A review," Environmental Engineering Science, vol. 27, no. 11, pp. 915-922, 2010.

[7] M. Branis, P. Rezacova, and M. Domasova, "The effect of outdoor air and indoor human activity on mass concentrations of PM10, PM2.5, and PM1 in a classroom," Environmental Research, vol. 99, no. 2, pp. 143-149, 2005.
[8] C. W. Bayer, S. Crow, and J. Fischer, "Causes of indoor air quality problems in schools," in Summary of Scientific Research, pp. 2427, US Department of Energy: Oak Ridge, Tennessee, Tenn, USA, 1999.

[9] J. D. Mcleod, Evaluation Of Indoor Air Quality Parameters And Airborne Fungal Spore Concentrations By Season And Type Of HVAC System in a School Building [Msc. thesis], 2008.

[10] G. Smedje, Y. Mi, L. Elfman, and D. Norbäck, "Ambient pollution and indoor air quality at school," Epidemiology, vol. 17, no. 6, 2006.

[11] N. Hazar, M. Karbakhsh, M. Yunesian, S. Nedjat, and K. Naddafi, "Perceived risk of exposure to indoor residential radon and its relationship to willingness to test among health care providers in Tehran," Journal of Environmental Health Science and Engineering, vol. 12, no. 1, article no. 118, 2014.

[12] K. Vimalanathan and T. R. Babu, "The effect of indoor office environment on the work performance, health and well-being of office workers," Journal of Environmental Health Science and Engineering, vol. 12, no. 1, article no. 113, 2014.

[13] J. Zhong, J. Ding, Y. Su et al., "Carbonaceous particulate matter air pollution and human exposure from indoor biomass burning practices," Environmental Engineering Science, vol. 29, no. 11, pp. 1038-1045, 2012.

[14] T. Hwang and J. T. Kim, "Assessment of indoor environmental quality in open-plan offices," Indoor and Built Environment, vol. 22, no. 1, pp. 139-156, 2013.

[15] C. C. L. Tan, K. N. Finney, Q. Chen, N. V. Russell, V. N. Sharifi, and J. Swithenbank, "Experimental investigation of indoor air pollutants in residential buildings," Indoor and Built Environment, vol. 22, no. 3, pp. 471-489, 2013.

[16] S. Dasgupta, M. Huq, M. Khaliquzzaman, K. Pandey, and D. Wheeler, "Indoor air quality for poor families: new evidence from Bangladesh," Indoor Air, vol. 16, no. 6, pp. 426-444, 2006.

[17] E. Bucur, A. Vasile, R. Diodiu, A. Catrangiu, and M. Petrescu, "Assessment of indoor air quality in a wooden church for preventive conservation," Journal of Environmental Protection and Ecology, vol. 16, no. 1, pp. 7-17, 2015.

[18] R.-B. Xiang, J.-B. Song, Y. Zhu, and W. Guang, "Indoor Air Quality in Kitchens in Rural China," Environmental Engineering Science, vol. 33, no. 9, pp. 699-704, 2016.

[19] World Health Organization (WHO). Global Urban Ambient Air Pollution Database, 2016, http://www.who.int/phe/ health_topics/outdoorair/databases/cities/en/.

[20] S. Yalcin, G. Aras, U. Akar Tarim, and O. Gurler, "Indoor radon levels in primary and secondary schools of Kastamonu, Turkey," Journal of Environmental Protection and Ecology, vol. 16, no. 1, pp. 18-22, 2015.

[21] International Commission on Radiological Protection (ICRP). Recommendations of the International Commission on Radiological Protection. vol. 21 No. 1990; 1-3, publication 60.

[22] United Nations Scientific Committee on the Effects of Atomic Radiation (UNSCEAR). 2000 Sources and effects of ionizing radiation: sources (Vol. 1). 2000, United Nations Publications. 

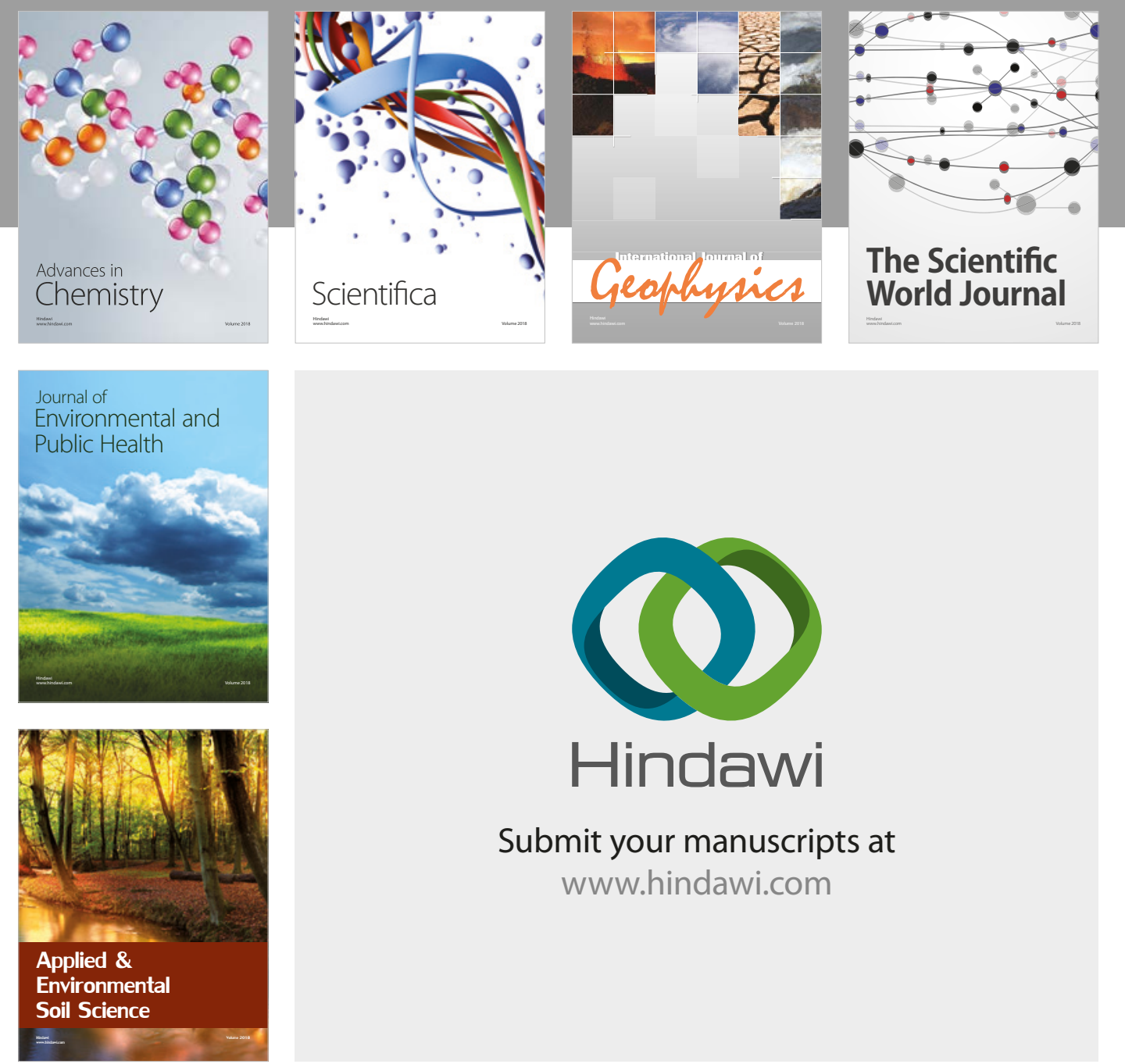

The Scientific

\section{World Journal}
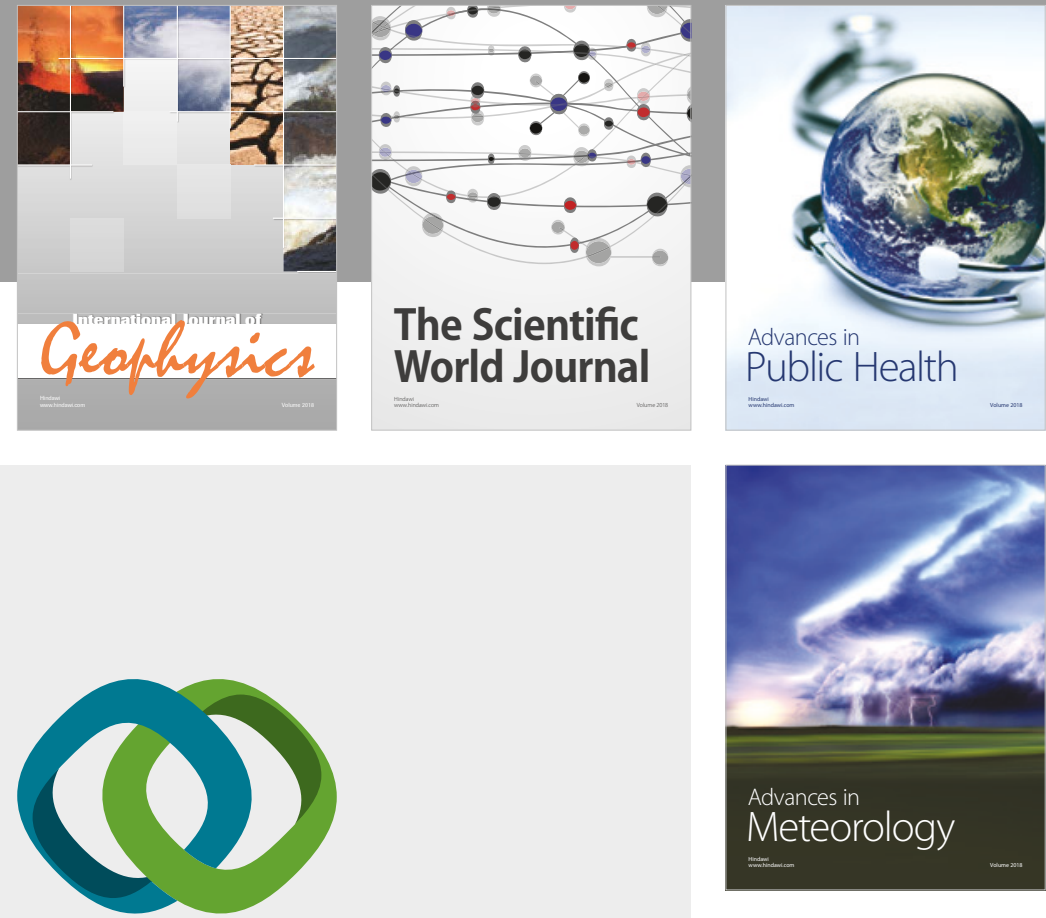

Advan

Public Health

\section{Hindawi}

Submit your manuscripts at

www.hindawi.com
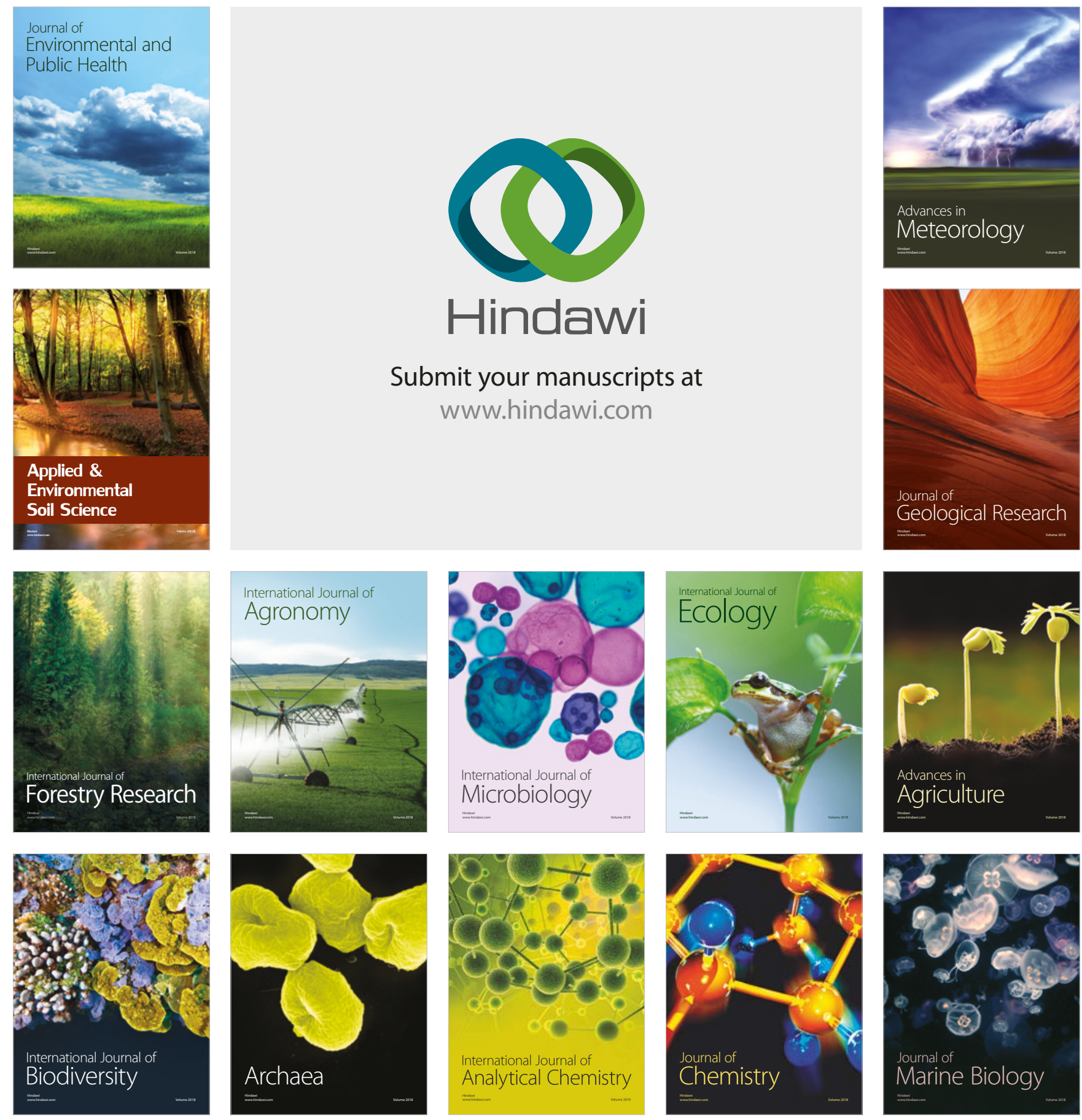